\title{
THE OMBUDSMAN ROLE IN THE REPUBLIC OF MACEDONIA AS A CONTROLLER OF THE STATE ADMINISTRATION WORK
}

\author{
Associate professor PhD Jadranka Denkova \\ University "Goce Delcev Faculty of law" \\ e-mail: jadranka.denkova@ugd.edu.mk; \\ Biljana Stoilova,
}

master`s student at the Faculty of Law at University "Goce Delchev"-Stip, Macedonia, e-mail: biljana.stoilova@yahoo.com;

\begin{abstract}
Refering to the primary role of the institutuion Ombudsman- human rights protection, it is important to ephasize the numerous measurements available within the scope of its competences. The purpose of this paper is to make analysis of one segment of the numerous competences, which is perceiving the actions and activities undertaken by the Ombudsman as a controller of the State bodies, i.e. State Administration in the Republic od Macedonia. Human rights and freedoms are mostly violated by suppliers of public services, and the Ombudsman is the one with a competence in the area of protecting the citizens from these bodies and institutions. In this protection precisely, the Ombudsman is directed towards controlling the legality as well as the appropriatness of the actions undertaken and the decisions made by the bodies of State Administration. Thus, reserach methodology is directed towards qualitative analysis of documents and statisical data dating from the period 2010-2014, relevant to the research subject. At the same time, by analyzing the annual reports of the Ombudsman in the Republic of Macedonia, as well as the number of complaints lodged by the citizens, we come to conclude that the legal settlement of the Ombudsman competences, limited solely to preventive actions, and not being authorized for making mandatory legal decisions while controlling the State bodies work, negatively affects the effective protection of the civil human rights and freedoms from State bodies and other oublic authorities.
\end{abstract}

Key words: rights, freedom, control, state bodies, protection

\section{Introduction}

Pursuant the current Law on the Ombudsman ${ }^{1}$ in Article 2 is stipulated that the Ombudsman is a body of the Republic of Macedonia that protects civil and individual constitutional and legal rights

\footnotetext{
1 ( „The Official Gazette of the Republic of Macedonia“ no.60/03 from 22.09.2003).
}

when violated by acts, actions, and lack of actions by the State Administration bodies and other bodies and organizations with public competences, which undertakes actions and measures for protection of the principle of non-discrimination and appropriate and equitable representation of communities in State bodies, local government departments bodies and public institutions and services.

The roots of this institution can be found even in antiquity, i.e. at the time of ancient Rome, China and Egypt. Sweden was the country that initially in the year 1809 introduced in its legal system such institution with the objective of creating and developing legality and civil rights and freedoms. The first Swedish Ombudsman Iars Augustin Monnerheimn was elected by the parlament on the first of March, $1810^{2}$. According to the former Law on the Ombudsman $^{3}$, the Ombudsman is a body of the Republic which protects civil constitutional and legal rights when violated by State Administration and other bodies provided with public competences.

Unlike the former Law on the Ombudsman where the notion of the Ombudsman was given in a narrow sense, in the current Law, the Ombudsman notion or definition is expanded and explained in detail. Therefore, by comparing the two Laws can be noted that in the current Law

\footnotetext{
2 Grizo, Gelevski, Davitkovski, Pavlovska - Daneva. (2011). „Administrative law “;

3 (,The Official Gazette of the Republic of Macedonia “ no. 7/97 from 20.02.1997).
} 
on the Ombudsman, the manner in which civil rights can be violeted is described (by acts, actions or lack of actions), by the State Administration authorities and other bodies and organizations with public competences; and additionaly the jurisdiction of the Ombudsman is expanded, providing it to be legally authorized to undertake actions and measures in order to protect the principles of non-discrimination and appropriate and equitable representation of communities in State bodies, local government departments bodies and public institutions and services.

In most countries, and in the Republic of Macedonia likewise, there is a special body which protects civil and individual constitutional and legal rights when violated by acts, actions, and lack of actions by the State Administration bodies and other bodies and organizations with public competences, which undertakes actions and measures for protection of the principle of non-discrimination and appropriate and equitable representation of communities in State bodies, local government departments bodies and public institutions and services, and this body is the Ombudsman.

The Ombudsman was initially established as an institution in the legal system of the Republic of Macedonia by the Constitution $^{4}$, which establishes the institution Ombudsman, thus adopting the first Law on the Ombudsman in 1997, subsequently adopting the current Law on Omudsman in 2003. ${ }^{5}$

The terms and conditions given in the society and the environment we live in are contributing for the increased interest if the state bodies act in a manner that respects civil and individual constitutional and legal rights, and moreover, who

\footnotetext{
4 (, The Official Gazette of the Republic of Macedonia“" no.52/91, no. 1/92, no. 31/98 and no.91/01) from 1991).

5 ( „The Official Gazette of the Republic of Macedonia“ no.60/03 from 22.09.2003).

controls and monitors the State bodies in order to protect these civil and idividual constitutional and legal rights when violated by State Administration and other bodies provided with public competences. Therefore, the way citizens should act when their guaranteed rights are violated by State bodies, local government departments bodies and public institutions and services, is of great significance. The concern for protecting individuals constitutional and legal rights is being left to the Ombudsman. Guided by this Ombudsman competence we set the research subject of this paper to perceive the significance of this function and the activities taken by him as a controller of civil bodies.

Bearing in mind the significance of the Ombudsman as a specific, special, expert and independent body provided with competences for protecting civil rights, in this paper we are going to review the analysis of data derived from statistics, as well as from legal acts, hence we will perceive his preventive and control function, considering the facet that the Ombudsman is not a legislative body, executive or judicial power, neither a State prosecutor nor body for inspection and supervision. Therefore, in this paper we will analyze his practice in making propositions, giving advices, suggestions, collaboration, giving instructions and possessing the skill to listen to people and to act in a timely manner in order to realize civil rights. The Ombudsman as an institution is transparent, making his office constantly available for every citizen of the Republic of Macedonia, or any other individual. In the realm of performing his function, the Ombudsman is independent and autonomous in his work, whereupon he performs actions resulting from his competences on the foundations and within the Constitution, the Law and the international laws ratified according to the Constitution. The main point of this paper is that the Ombudsman function is directed towards controlling legality, as 
well as the appropriatness of the actions undertaken and the decisions made by the bodies of State Administration.

The Ombudsman is an independent autonomous body which is liable for its work to the legislative body, i.e. the Parliament and it is obliged to deal with civil complaints and to take its own initiative when it notices irregularities in the work of the Administration bodies, thus violating the fundamental human rights and freedoms, at the same time providing that all the legal means for adequate protection are exhausted.

\section{The competences of the Ombudsman in the direction of performing control over the administration and clerks}

In this part, through analysis of laws and regulations we will perceive the overall competence of the Ombudsman in the Republic of Macedonia as a controller of the State bodies. As previously stated, when we look through the Law on Ombudsman, we will realize that this institution is a body of the Republic of Macedonia which protects civil and individual constitutional and legal rights when violated by acts, actions, and lack of actions by the State Administration bodies and other bodies and organizations with public competences, which undertakes actions and measures for protection of the principle of nondiscrimination and appropriate and equitable representation of communities in State bodies, local government departments bodies and public institutions and services. ${ }^{6}$

The Ombudsman competences are determined by the Law on the Ombudsman and the Ombudsman's Rules of procedure ensures proper, methodical and accurate acting within the Ombudsman competences. One of the Ombudsman competences is undertaking actions and measures for protection of the principle of non-discrimination and appropriate and equitable representation of communities in State bodies, local government departments bodies and public institutions and services. Typical of the Ombudsman is the role of a body that serves as an additional tool in terms of mechanisms for protecting civil rights, directed towards controlling the legality as well as the appropriatness of the actions undertaken and the decisions made by the bodies of State Administration. The immense validity of the Ombudsman as a protector of civil rights and freedoms is indisputable, both because the competences available to assist the citizen (demanding that the Administration body review its own decision by giving it advice and suggestions; publishing remarks and critiques about the work of certain Administration bodies in the media etc.) and because of the psychological effect it has on citizens and clerks. The psychological effect is achieved due to the Ombudsman existence solely, because it affects the citizens and clerks, even when it doesn't perform concrete action. Citizens are often satisfied by the mere fact that there is somone to address to, when thay believe their rights have been violated. On the other hand, the institution Ombudsman has a positive effect on the clerks work, since sometimes simply knowing that someone monitors and controls their work is enough, whereupon every mistake or irregularity made by them can be noticed by the Ombudsman or by the unsatisfied citizens. $^{7}$

The Ombudsman lacks the authority to make decisions, he only intervenes by suggesting, making remarks, giving recommendations, proposals etc. These interventions should be respected mostly because they are made by an independent autonomous body equiped with

\footnotetext{
7 Grizo, Gelevski, Davitkovski, Pavlovska - Daneva. (2011).
} „Administrative law “; 
professionalism, expertise, objectivity and impartiality. Typical for the ombudsman interventions is that a complaint is not anticipated, so for every failure there is the public opinion and the media ${ }^{8}$. According to the Law on the Ombudsman, the Ombudsman initiates proceeding when citizens ask for initiation by complaint, or at its own initiative. The petition in fact represents a request for inquiry when the citizen believes that some of his constitutional rights has been infringed, both by Administration bodies and by organizations with public authorities.

When the initiative to set up an inquiry comes form the Ombudsan, a permission from the individual whose rights are violated is required. Hence it is nessesary to percieve the possibility of the Ombudsman to ask the State authorities to update him for the measures being undertaken within 30 days. At this point, it should be stated the authority of the Ombudsman to inform the superior body, the competent ministry, the Government of the Republic of Macedonia, the Parliament or to publish it in the media, in case of not receiving the nessessary information within 30 days. Particulary prominent is the Ombudsman function to aks for modification of the legislations and assessment of the constitutionality and the legality, if he finds out that the violation of the constitutional and legal rights resulted from a regulation that is not in accordance with the Constitution and the Laws. It is essential to emphasize the Ombudsman authority to inspect the State administration bodies and other bodies with public authorities, without prior notice, as a way of monitoring the situation in the field of civil rights and freedoms.

The Ombudsman possess the legal authority to request for explanations and

\footnotetext{
${ }^{8}$ Grizo, Gelevski, Davitkovski, Pavlovska - Daneva. (2011) "Administrative law “.
}

information from the Bodies, to interview an official or a clerk of a certain organization, or to ask scientific institutions for opinion in order to get a complete picture of the issue.

At the begining of the proceeding, the Ombudsman proposes negotiated settlement when the circumstances allow it, provided that the negotiation is in accordance with the Constitution and the Laws.

During the proceeding, the Ombudsman may invoke the principle of equity, when the circumstances result in obvious inequity created by the application of legal provision.

While following the situation for the appropriate and equitable representation of communities, the Ombudsman acts: upon a petitions; on his own initiative if somehow it comes to the conclusion that these principles are not respected; upon conducted inspections of the bodies, organizations and institutions; by following the stipulations in the programme of the bodies and organizations; by keeping track on the advertisements for employing staff in the institutions which are obliged to respect the constitutional principles.

In order to secure obeying the constitutional and legal rights and principles of non-discrimination and appropriate and equitable representation of community members, the Ombudsman can, on his own initiative, submit reccomendations, opinions and critiques to the bodies within its competence, provided it concludes that by certain general or individual acts, performed by actions and lack of actions by the above mentioned bodies and organizations, these rights and principles are disobeyed; or if there are no legal mechanisms for compliance and realization of civil rights and for fulfilment of these principles in terms of community members. 
Violation of human and constitutional rights can be done in deifferent areas, in varying forms and ways: intentional and unintentional, bureaucratic, arbitrary, inappropriate and inhuman behaviour, lack of acting upon a civil complaint, not adopting an act, decision, conclusion, not providing a certificate, opinion etc., delaying a proceeding, unequal treatment, inaccurate act, act based on incorrect and incomplete factual situation, act based on unsuitable substantive act, violated procedure and any other kinds of intentional or unintentional behaviour and actions which violate civil rights and freedoms guaranteed by the Constitution, laws and international ratified contracts and conventions.

\section{Analysis of the results}

Subsequent of the previous analysis of the legal documents relevant to the research subject, in this section official statistical data derived from the Ombudsman's reports for the period from 2010 to 2014 will be analysed. Most of the complaints that initiated action by the Ombudsman of the Republic of Macedonia were submitted in 2012- 5220 complaints in total, of which 4346 complaints from 4778 citizens were submitted during 2012, and the other 874 were transferred from the previos year (Annual report of the Ombudsman for 2012).

The 2011 is next, when the Ombudsman acted upon a total of 5074 complaints, of which 4256 complaints from 4711 citizens were submitted during 2011 (Annual report of the Ombudsman for 2011).

According to the number of complaints that initiated acting of the Ombudsman of the Republic of Macedonia, 2014 is next, when it acted upon a total of 4995 complaints of which 4249 were submitted by 4331 citizen during 2014, and the other 746 were transferred from the previous year. (Annual report of the Ombudsman for 2014).

It is followed by 2010 when the Ombudsman acted upon a total of 4827 complaints, of which 4043 complaints were submitted by 4125 citizens during 2010.(Annual report of the Ombudsman for 2010).

The lowest number of complaints upon which the Ombudsman performed action was during 2013- a total of 4599 complaints of which 3780 were submitted by 4041 citizen in 2013, and the other 819 were transferred from the previous year. (Annual report of the Ombudsman for 2013).

The largest number of complaints were recieved in the field of judiciary during 2014 (21,20\%), 2013 (19,37\%), $2011(17,20 \%)$ и $2010(18,72 \%)$. Except in 2012 when the largest number of complaints was submitted in the field of consumer rights $(21.81 \%)$.

The number of complaints whose proceeding was finished in the same year it was initiated will be graphically represented below. The largest number of completed procedures was recorded in 2012 (high $84.31 \%$ of the cases), and the lowest number of completed procedures upon submitted complaints was recorded in 2014 (only $81.32 \%$ of cases). 


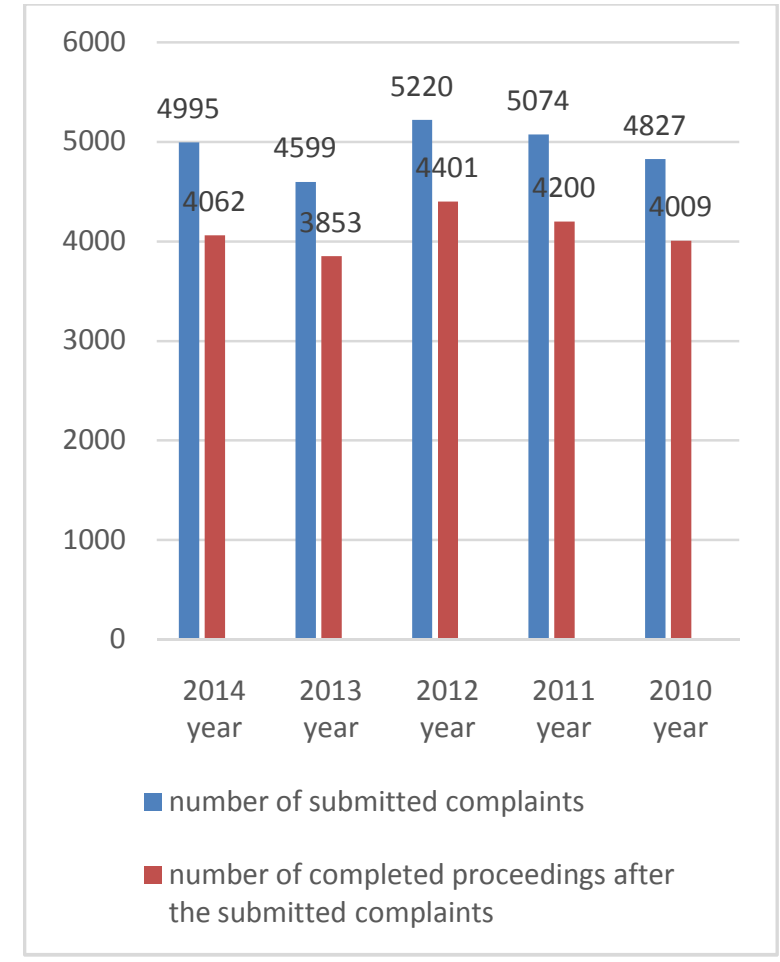

Concerning the number of proceedings where violations of civil rights and freedoms were found, and the number of cases upon which interventions have been accepted by the State administration bodies, other bodies and organizations with public competences, we provide the following figure:

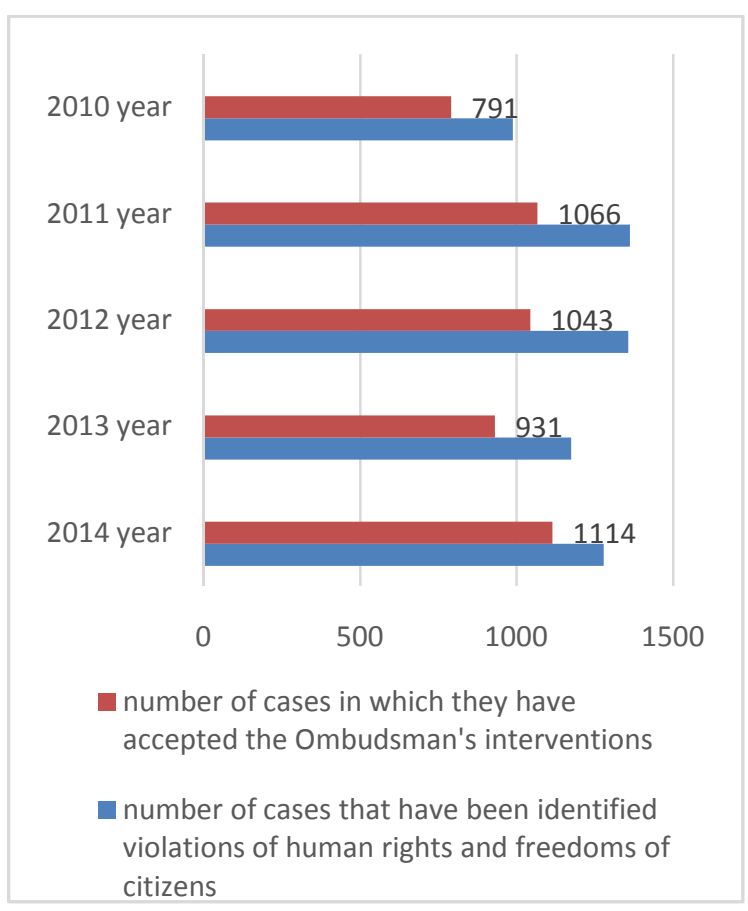

070634248 Aleksandar Regarding the bodies which in most cases did not acted according the directives, suggestions, recommendations, opinions and other Ombudsman interventions, we state the following:

- 2014- Ministry of Internal Affairs, local government departments, Penitentiary, State Commission for administrative procedure and employment in the second instance, Ministry of Finance, Ministry of Health, the Health insurance Fund etc.. .(Annual report of the Ombudsman for 2014).

- 2013- Ministry of Health, local government departments, Ministry of Finance, Ministry of Internal Affairs, Ministry of Labor and Social politics etc. .(Annual report of the Ombudsman for 2013).

- 2012-Ministry of Internal Affairs, local government departments, public enterprises, agencies and institutions, State Commission for administrative procedure and employment in the second instance, Ministry of Health, Ministry of Labor and Social politics etc. .(Annual report of the Ombudsman for 2012).

- 2011- Ministry of Finance, complaint committees of the Government, Ministry of Internal Affairs, local government departments etc. .(Annual report of the Ombudsman for 2011).

- 2010- complaint committees of the Government, Ministry of Internal Affairs, Ministry of Finance, Ministry of Health, local government departments etc. .(Annual report of the Ombudsman for 2010).

We can reach a conclusion of the above that the majority of the State bodies did not act in compliance with the Ombudsman's recommendation, whereas additional actions related to the responsibility of the state employees have not been taken.

Thus, we can confirm that the Ombudsman's control of the State bodies is limited solely to reports regarding the lack of action according to its recommendations. 
Furthermore, Ombudsman's activities such as making propositions, giving advices, suggestions, collaboration, giving instruction, education on prevention and control of the state bodies' activities. Undertaking other measures to affect the increasing the administration's efficiency and responsibility are not observed.

\section{Conclusion}

As a conclusion of this paper we can deduce certain claims base on relevant indicators. Out of the total results, we can conclude that the confidence in the Ombudsman is increasing, which is evident from the constant proliferation of the civil complaints submitted. Considering the organizational structure and the legal competence of the Ombudsman to be prevented from making concrete decisions whilst controlling the state bodies, it has a negative effect on protecting civil rights and freedoms from state bodies and other public authorities. The paper provides clear outcome in terms of the Ombudsman's competence to control the appropriate or inappropriate treatment of the State administration bodies and other public authorities, as a basis for determining the liability of state bodies for violating civil and individual rights. In addition, the paper gives insight into the fact that due to the Ombudsman's lack of competence for decision making, there is a negative impact on the obedience of the state bodies, other bodies and public authorities that violated the civil rights, showing reduced acceptance and keeping to the Ombudsman's interventions. At the same time we can conclude that preventive measures or public critiques undertaken by the Ombudsman have not be noted, as an answer to the refusal of the state bodies to follow its directives. This indicates that the Ombudsman does not use all the available instruments to impel state bodies to responsible functioning. The previosly mentioned insights can serve as a basis or a benchmark for taking the next steps towards improvment of the Ombudsman's role as a controller of state bodies, in addition to strengthening the Ombudsman's role, with the emphasis on improving its function as a controller of the responsible working of the state bodies,i.e. the state administration. The question arises whether a modification of the model of the Ombudsman as an independent body is necessary, hence his appointment and dismisal is done by the Parliament, where the dominant ruling party makes the decisions. Thus, the Ombudsman is cautious while criticizing the authorities of the state bodies and administration, so this would not reflect negatively on his function.

\section{References:}

- Grizo, Gelevski, Davitkovski, Pavlovska - Daneva. (2011). ,Administrative law “;

- Annual report of the Ombudsman for 2014. Retrieved from: http://ombudsman.mk/upload/Godisni\%20izvestai/G I-2014/GI\%202014.pdf; Last visited:20.12.2015.

- Annual report of the Ombudsman for 2013. Retrieved from: http://ombudsman.mk/upload/Godisni\%20izvestai/G I-2013.pdf; Last visited:20.12.2015.

- Annual report of the Ombudsman for 2012. Retrieved from: http://ombudsman.mk/upload/Godisni\%20izvestai/G I-2012/GI-2012.pdf; Last visited:20.12.2015.

- Annual report of the Ombudsman for 2011. Retrieved from: http://ombudsman.mk/upload/Godisni\%20izvestai/G I-2011/Izvestaj\%202011-MK.pdf; Last visited:20.12.2015.

- Annual report of the Ombudsman for 2010. Retrieved from: http://ombudsman.mk/upload/documents/Izvestaj\%2 02010-MK.pdf; Last visited:20.12.2015.

- Dimitrovski, R.; Kekenovski, J. (2007). Public administration. Skopje.

- The Rules of procedure of the Ombudsman. („The Official Gazette of the Republic of Macedonia " no. 11/05);

- The Law on the Ombudsman. („The Official Gazette of the Republic of Macedonia" no.60/03 from 22.09.2003).

- Law amendment and reform of the law on 
(JPMNT) Journal of Process Management - New Technologies, International

Vol. 4, No.2, 2016.

Ombudsman. (,The Official Gazette of the Republic of Macedonia" no.114 from 14.09.2009).

- The Law on the Ombudsman (out of use). („The Official Gazette of the Republic of Macedonia “ no. 7/97 from 20.02.1997).

- M.Fromont; Administrative law of the European countries;

- Pavlovska- Daneva.(2000). „Ombudsman “, Skopje.

- The Constitution of the Republic of Macedonia. (,The Official Gazette of the Republic of Macedonia“" no.52/91, no. 1/92, no. $31 / 98$ and no.91/01 from 1991).

- J.M.Shafritz,E.V.Rasel и K.P.Borik; Introduction in public administration;

- Shkarikj, S.; Siljanovska- Davkova, D ; (2007) . Constitutional Law. Ss. "Cyril and Methodius" Faculty of Law " Justinian I" - Skopje.

- Retrieved from: http://ombudsman.mk/; Last visited:20.12.2015.

- Retrieved from: http://www.osce.org/skopje/87913?download=true; Last visited:20.12.2015.

- Retrieved from: http://www.akademik.mk/document/narodenpravobranitel; Last visited:20.12.2015.

- Retrieved from: http://www.sobranie.mk/ustav-narm.nspx; Last visited:20.12.2015.

- Retrieved from: http://www.morm.gov.mk/wpcontent/uploads/Odluka-za-proglasuvanje-naamandmanite-IV-V-VI-VII-VIII-IX-X-XI-XII-XIIIXIV-XV-XVI-XVII-I-XVIII-NA-USTAVOT-NAREPUBLIKA-MAKEDONIJA.pdf; Last visited:20.12.2015.

- Retrieved from: http://24vesti.mk/zgolemenadoverbata-na-gragjanite-vo-narodniot-pravobranitel; Last visited: 20.12.2015. 